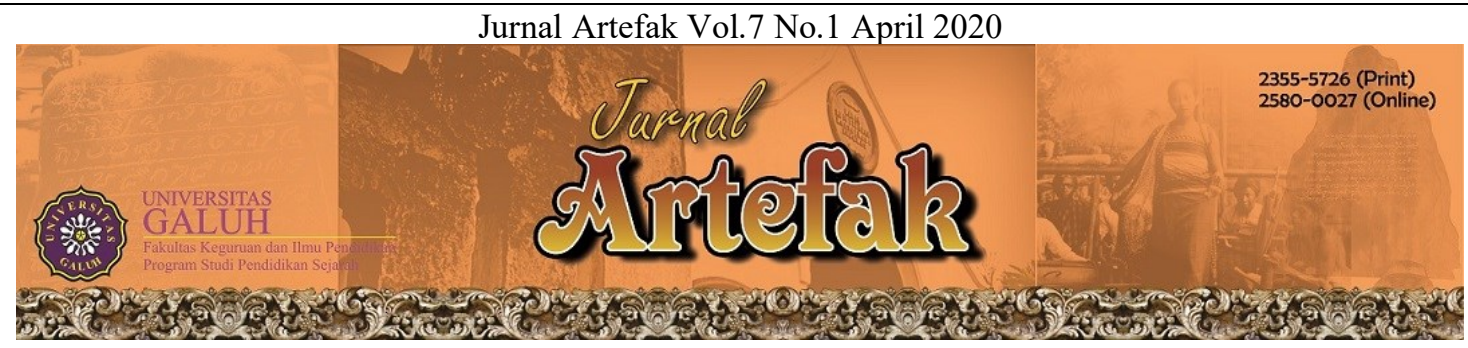

https://jurnal.unigal.ac.id/index.php/artefak

\title{
TRADISI OROM SASADU DALAM SUKU SAHU TALAI DI WORAT-WORAT
}

\author{
Gomer Rionaldo Sipondak ${ }^{1}$, Jamin Safi $^{2}$, Suharlin Ode Bau ${ }^{3}$ \\ Program Studi Pendidikan Sejarah, STKIP Kie Raha Ternate, Indonesia \\ e-mail: gomersipondak11@gmail.com¹; jaminsafii@gmail.com²; odesuharlin@gmail.com ${ }^{3}$ \\ Sejarah Artikel: Diterima: 12-3-2020 Disetujui: 4-4-2020 Dipublikasikan: 5-4-2020
}

\begin{abstract}
Abstrak
Penelitian ini bertujuan untuk mengetahui persepsi masyarakat tentang tradisi orom sasadu, prosesi tradisi orom sasadu suku Sahu Talai, serta makna dan nilai tradisi orom sasadu dalam suku Sahu di Desa Worat-Worat. Metode yang duganakan adalah metode kualitatif tipe fenomenologi. Hasil penelitian menunjukan bahwaprosesi upacara adat yang dilaksanakn pada masa ini juga memberi kesan kepada masyrakat Worat-Worat untuk selalu bersyukur atas hasil alam tersebut dalam prosesi upacara adat sehingga prosesi ritual adat orom sasadu patut dilestarikan. Prosesi ritual adat orom sasadu meliputi masa persiapan, yaitu dilaksanakan pertemuan-pertemuan adat antara masyarakat, kepala desa serta perangkat adat untuk membahas waktu pelaksanaan tradisi ritual adat orom sasadu. Pembukaan yakni menggantungkan kain putih berbentuk segi tiga mengelilingi sasadu dan pengibaran bendera induk. Pelaksanaan, yaitu makan secara bersama-sama sebagai wujud ucupan syukur kepada Tuhan atas hasil panen yang ada. Serta penutupan, yakni penurunan bendera induk (paji) di bumbungan rumah adat dan melepaskan kain putih yang berbentuk segi tiga dengan dilepaskannya kain putih berbentuk segi tiga yang digantung mengililingi sasadu, maka acara makan bersama di rumah adat atau orom sasadu dinyatakan berakhir dan masyarakat suku Sahu kembali ke kegiatan rutin keseharian mereka. Melalui orom sasadu, masyarakat Woratworat juga diajarkan untuk memaknai hubungannya dengan lingkungan alam sekitar, hubungan sesama manusia, dan relasi deng yang Maha Kuasa. Nilai yang terkandung dalam tradisi orom sasadu yakni nilai sosial, nilai moral, nilai kebersamaan atau gotong royong, dan nilai religius. Tradisi orom sasadu perlu dilestarikan karena dibalik prosesi upacara adat tersebut tersimpan makna dan nilai yang baik.
\end{abstract}

Kata Kunci: Tradisi orom sasadu, Suku Sahu Talai, Worat-Worat

\begin{abstract}
This study aims to determine people's perceptions about the Somsadu Orom tradition, the Sahu Talai Orom tradition procession, and the meaning and value of the Sosadu Orom tradition in the Sahu tribe in the Worat-Worat Village. The proposed method is a qualitative method of phenomenology type. The results showed that the process of traditional ceremonies carried out at this time also gave an impression to the people of Worat-Worat to always be grateful for the natural products in the procession of traditional ceremonies so that the ritual procession of the orom sasadu customs should be preserved. The orom sasadu traditional ritual procession includes a preparation period, i.e. held customary meetings between the community, the village head and customary apparatus to discuss the timing of the orom sasadu traditional ritual. The opening is to hang a white cloth in the shape of a triangle around the sasadu and raising the main flag. Implementation, which is eating together as a form of thanksgiving to God for the existing crops. As well as closing, namely the reduction of the flag of the parent (paji) in the bumbungan of traditional houses and releasing a white cloth in the form of a triangle with the release of a white cloth in the shape of a triangle hanging around the sasadu, then the meal together at the traditional house or sasadu orom is declared over and the Sahu tribe community back to their daily routine. Through orom sasadu, the Woratworat community is also taught to interpret its relationship with the surrounding natural environment, human relations, and relations with the Almighty. The values contained in the Orom Sasadu tradition are social values, moral values, the value of togetherness or mutual cooperation, and religious values. Orom Sasadu tradition needs to be preserved because behind the traditional ceremonial procession is stored meaning and good value.
\end{abstract}

Keyword: Sosadu orom tradition, Sahu Talai tribe, Worat-Worat 


\section{PENDAHULUAN}

Indonesia merupakan negara kepulauan dengan beragam suku, ras, dan agama. Ragam suku ini mendiami pulau-pulau yang tersebar diseluruh penjuru nusantara. Banyaknya suku yang ada di Indonesia, menjadikan negara ini memiliki ragam budaya yang setiap kelompok masyarakat masing-masing memiliki tradisi dan adat istiadat yang terus dilestarikan. Tradisi secara garis besar merupakan suatu budaya dan adat-istiadat yang diwariskan dari satu generasi ke generasi lainnya yang diimplementasikan dalam wujud kehidupan sehari-hari. Tradisi tersebut diyakini dan telah terbukti sebagai sarana yang mampu menggalang persaudaraan dan solidaritas antar warga yang yang telah melembaga dalam tatanan sosial dan budaya. Menurut Soekanto (2006:181), tradisi adalah perbuatan yang dilakukan berulang-ulang di dalam bentuk yang sama dan merupakan suatu kebiasaan yang teraplikasikan secara terus menerus dengan berbagai simbol dan aturan yang berlaku pada sebuah komunitas.

Kebiasaan masyarakat yang dilaksanakan secara turun temurun karena dipandag memiliki nilai positif dalam pergaulan masyarakat. Menurut Esten (1992:14), tradisi adalah kebiasaan yang turun-temurun dalam sekelompok masyarakat berdasarkan nilai budaya masyarakat yang bersangkutan. Tradisi memperlihatkan bagaimana anggota masyarakat bertingkah laku, baik dalam kehidupan yang bersifat gaib atau keagamaan. Salah satu tradisi yang terus dilestarikan Sahu, yaitu tradidi orom sasadu.

Tradisi orom sasadu merupakan suatu tradisi yang terdapat di Provinsi Maluku Utara yang lebih tepatnya berada di Kabupaten Helmahera Barat, khusunya pada masyarakat Sahu yang berasal dari dua suku, masingmasing suku Talai dan Padi Sua. Keturunan dari dua suku bangsa ini menyebar ke desadesa yang ada di kecamata Sahu dan Sahu Timur. Masing-masing adalah suku talai menyebar ke desa Worat-worat, Golo, Tamome, Balesoan, Idam, dan desa Loce.
Sedangkan suku Padi Sua menyebar antara lain ke desa Taraudu, Awer, Akelamo, Aketola, Padosoa, Tibobo, Hokogama, Ngapanyira, Gamnyial, Campaka, dan Gamsungi. Walaupun hidup dan tinggal terpisah-pisah, tetapi pada umumnya memiliki adat dan budaya yang sama.

Tradisi orom sasadu merupakan ritual adat masyarakat Sahu pada umumnya dan masyarakat Worat-Worat khusunya merupakan upacara adat yang telah dilaksanakan oleh para leluhur masyarakat suku Sahu Talai yang berada di Desa Worat-Worat, dilaksanakan hanya pada saat panen raya dan pelaksanannya hanya sekali dalam setahun, sehingga peneliti berasumsi bahwa pada masa lalu masyarakat Worat-worat sangat giat dalam bercocok tanam padi guna memperoleh hasil panen yang sangat banyak. Pelaksanaannya tradisi orom sasadu bagi masyarakat WoratWorat hanya sebatas memperingati kemakmuran masyarakat pada saat panen raya.

Menurut Shils dalam Sztomka (2001:70). bahwa tradisi berarti segala sesuatu yang disalurkan atau diwariskan dari masa lalu ke masi kini. Orom sasadu merupakan tradisi masa lalu yang terus diwariskan secara turun temurun. Hal ini dalam pelaksanaannya dapat dilihat dalam masyarakat Worat-worat. Orom sasadu dilaksanaan pada pertengahan tahun yang merupakan waktu untuk memanen padi yang dilaksanakan secara rutin oleh masyarakat Worat-Worat. Secara tidak langsung tradisi orom sasadu telah membuka polah pikir masyarakat Worat-Worat terhadap kamakmuran masyarakat Worat-Worat pada masa lalu dan pandangan hidup masyarakat Worat-Worat ke depannya terhadap tradisi tersebut.

Walaupun demikian, tradisi orom sasadu hingga saat ini masih dilestarikan karena tersimpan nilai atau makna yang positif dari tradisi orom sasadu tersebut, sehingga perlu dilestarikan dan diwariskan kepada generasi penerus. Penelitian ini bertujuuan untuk mengetahui (1) persepsi masyarakat Worat-worat terhadap tradisi orom sasadu, (2) prosesi upacara adat orom sasadu di desa 
Worat-worat, dan (3) makna dan nilai tradisi orom sasadu di desa Worat-worat.

\section{METODE PENELITIAN}

Penelitian ini menggunakan jenis kualitatif. Moleong (2014:6) menyatakan bahwa penelitian kualitatif adalah penelitian yang bermaksud untuk mengetahui fenomena tentang apa yang dialami oleh subjek penelitian misalnya: perilaku, persepsi, motivasi, tindakan dan lain-lain Sedangkan tipe yang digunakan dalam penelitian ini adalah fenomonologi. Menurut Sutopo (2006: 27) fenomenologi memendang perilaku manusia, apa yang mereka katakan dan apa yang mereka lakukan adalah sebagai suatu produk dari bagaimana orang melakukan tafsir terhadap dunia mereka sendiri. Pendekatan ini lebih menekankan rasionalisme dan realitas budaya yang ada yang berusaha memahami budaya lewat pandangan pemilik budaya atau pelakunya yang berusaha untuk menjelaskan bagaimana fenomena itu tersusun serta berusaha memahami fenomena sebagai objek kesadaran.

Penelitian ini dilakukan di Desa WoratWorat, Kecamatan Sahu, Kabupaten Halmahera Barat, Provinsi Maluku Utara. Teknik pengambilan informan dengan cara sampling. Informan yang diambil benar-benar tahu tentang tradisi orom sasadu. Informan dalam penelitian ini adalah tokoh adat dan tokoh masyarakat. Jenis data dan sumber data dalam penelitian ini, yaitu informan/ narasumber, tempat dan peristiwa/aktivitas, serta arsip dan dokumen.

Teknik pengumpulan data dilakukan dengan menggunakan wawancara, dalam teknik ini peneliti mengadakan wawancara langsung dengan orang-orang yang dianggap lebih tahu mengenai tradisi orom sasadu tersebut baik pemuka adat maupun tokoh masyarakat; observasi, dalam teknik ini peneliti mengamati, mencatat, serta menganalisis suatu objek dengan sistematika fenomena yang diselidiki; dan studi dokumentasi, merupakan pengumpulan data oleh peneliti dengan cara menggumpulkan dokumen-dokumen dari sumber yang terpercaya kemudian dianalisis. Untuk menguji keabsahan data, penelitian ini menggunakan teknik triangulasi, yaitu triangulasi data/ sumber dan triangulasi metode. Sedangkan teknik analisis data dalam penelitian ini menggunakan model interaktif (Miles dan Huberman, 2014: 16-19), yaitu reduksi data, penyajian data, dan penarikan kesimpulan/ verifikasi.

\section{HASIL PENELITIAN DAN PEMBAHASAN}

\section{Persepsi Masyarakat Worat-Worat Terhadap Tradisi orom sasadu}

Sasadu memiliki multi fungsi sebagai pemersatu masyarakat Worat-Worat, yang menopang proses dan relasi sosial dalam masyarakat Worat-Worat. Demikian para individu dalam masyarakat yang berbeda akan mengalami juga proses sosialisasi yang berbeda, karena proses sosialisasi itu banyak ditentukan oleh susunan kebudayaan dan linkungan sosial yang bersangkutan (Koentjaraningrat, 2002:232). Sasadu dalam konteks masyarakat suku Sahu Talai di WoratWorat, merupakan suatu perangkat nilai sosial yang disimbolkan dengan suatu bangunan publik. Simbol-simbol kultural sangat berperan penting dalam setiap perkembangan peradaban suku Sahu Talai. Menurut Hikmansyah (2016) Fungsi utama rumah adat sasadu, yaitu: 1) Tempat pelaksanaan upacara adat. 2) Dalam kehidupan sosial kemasyarakatan sebagai tempat pelaksanaan musyawarah adat. Terlepas dari posisi antara kelompokkelompok kekerabatan, ada posisi lain yang universal, yaitu antara peserta pria dan wanita. Sasadu merupakan simbol yang dalam sejarah suku Sahu berfungsi sebagai ideologi yang membentuk suatu kesadaran akanidentitas sosial sebagai masyarakat sasadu, Hal ini juga 
dikemukakan oleh Ham Kololi (Tokoh Masyarakat) pada saat wawancara yakni:

"tradisi orom sasadu merupakan tradisi masyarakat Worat-Worat yang telah dilaksanakan pada masa silam sebagai wujud ucapan terima kasih kepada yang Maha Kuasa atas hasil penen padi dengan melimpah. Meskipun pelaksanaan tradisi orom sasadu pada masa kini tidak lagi disertai dengan adanya proses panen padi tetapi tradisi orom sasadu tetap harus di laksanakan sebagai wujud mengenang kemakmuran masyarakat Worat-Worat pada masa silam sebagai pemberitahuan bagi masyarakat WoratWorat yang hidup pada saat ini untuk selalu bercocok tanam" (21/04/2019).

Selanjutnya Gaspar Yunga (Tokoh Adat) menjelaskan bahwa cara berkebun pada masa lalu adalah sebagai berikut:

“1) Joboron merupakan pembersihan lahan. Tahapan ini dilakukan dengan menggunakan peralatan seperti kapak dan parang; 2) Medawel merupakan pembersihan lahan dari tanaman besa;

3) Romen merupakan proses pembakaran rumput dan kayu pada lahan penanaman padi; 4) Babaris merupakan proses pembersihan lahan dengan menggunakan sapu yang terbuat dari daun pohon aren dan bambu sebagai pegangannya; dan 5) Tujuu, akhirnya lahan padi siap untuk ditanam" (12/05/2019).

Tradisi adalah perbuatan yang dilakukan berulang-ulang di dalam bentuk yang sama dan merupakan suatu kebiasaan yang teraplikasikan secara terus menerus dengan berbagai simbol dan aturan yang berlaku pada sebuah komunitas (Soekanto, 2006:181). Tradisi sering dipergunakan karena berkaitan dengan kebiasaan yang sudah melekat pada masyarakat. Dalam hal ini, tradisi memiliki arti secara umum, yang dimaksudkan untuk menunjukan nilai, norma, dan adat kebiasaan yang sudah lama lahir hingga sekarang masi diterima, diikuti bahkan dipertahankan oleh masyarakat yang bersangkutan. Adat kebiasaan disepakati untuk dipegangi bersama dan merupakan sistem nilai yang mempengaruhi perkembangan jiwa masyarakat pendudukannya sekaligus menjadi sumber etika dalam kehidupan bersama (Jamaludin, 2015: 300302).

Pelaksanaan tradisi orom sasadu yang di laksanakan pada masa kini, tanpa adanya proses penanaman padi di ladang namun mengadakan acara syukuran setelah panen yakni tradisi orom sasadu. Hal ini juga dikatakan oleh Leksi Gam (tokoh masyarakat) yakni:

"Meskipun prosesi Adat tersebut memiliki perbedaan pada masa kini dan masa yang lalu, bagi masyarakat WoratWorat bukanlah menjadi sebuah masalah dalam pelaksanaan tradsi orom sasadu Tersebut namun masyarakat Woratworat berpendapat bahwa pelaksaan tradisi orom sasadu pada masa kini, sebagai wujud dari pelestarian kebudayaan yang telah ada pada masa lalu guna untuk memperkenalkan kemakmuran masyarakat Worat-worat pada masa lalu kepada generasi masyarakat Worat-Worat baik sebagai generasi penerus pada masa kini maupun generasi pada masa yang akan dating” (25/04/2019).

Upacara makan bersama di rumah adat sasadu pada masa lalu perayaannya berbeda dengan pada saat ini, karena perayaan orom sasadu pada masa lalu digelar pada saat panen padi, sebagai ucapan syukur atas hasil padi terasebut. Tanpa adanya panen padi pada masa kini tradisi orom sasadu tetap dilaksanakan prosesi upacara adatnya. Hal ini dikarenakan pada perayaan saat ini tradisi orom sasadu mengajarkan masyarakat Worat-Worat untuk selalu mensyukuri hasil alam yang ada seperti hasil panen kelapa, pala, cengkeh, buahbuahan, dan lain-lain.

Prosesi upacara syukuran yang dilaksanakan saat ini masi sama dengan yang dilaksanakan pada masa lalu, namun sumber makan yang disediakan bukan dari hasil panen padi masyarakat Worat-Worat. Makanan yang 
disediakan oleh masyarakat Worat-Worat misalnya beras dibeli oleh masyarakat WoratWorat dengan menggunakan uang dari hasil panen yang lain, misalnya hasil panen kelapa, pala, cengkih, buah-buahan dan yang lainnya. Hal ini secara tidak langsung prosesi upacara adat yang dilaksanakan pada masa ini juga memberi kesan kepada masyarakat WoratWorat untuk selalu bersyukur atas hasil alam.

\section{Prosesi Upacara Adat Orom sasadu}

Upacara adat orom sasadu telah dilaksanakan pada masa lalu oleh masyarakat Worat-Worat. Proses perkembangan kebudayaan umat manusia pada umumnya yang sederhana, sehingga bentuk-bentuk yang lama semakin kompleks, yaitu evolusi kebudayaan (Fathoni, 2006:23). Pada masa lalu tradisi orom sasadu dilaksanakan dua kali dalam setahun yakni pada masa celuda (proses penanaman padi) dan $u t u$ (pada masa panen padi). Orom sasadu, pada masa celuda digelar di masing-masing lahan oleh masyrakat Worat-Worat, yang acaranya tidak terlalu ramai karena hanya sekedar merayakan proses menaman padi secara individu oleh masyarakat Worat-Worat, sedangkan pelaksanaan tradisi orom sasadu pada masa utu digelar di rumah adat sasadu yang perayaannya dilakukan secara bersama-sama oleh masyarakat Worat-worat sebagai wujud dari rasa syukur kepada Tuhan, atas hasil panen padi yang melimpah.

Pelaksanaan tradisi orom sasadu yang dilaksanakan pada masa lalu selama tujuh hari tujuh malam dengan makanan yang disediakan oleh masyarakat Worat-Worat dari hasil panen padi tersebut, yang mendasari digelarnya tradisi orom sasadu selama tujuh hari tujuh malam karena selama enam bulan masyarakat Worat-Worat memiliki kesibukan tersendiri di masing-masing lahan sehinggi tidak ada waktu untuk melakukan kegiatan Sosial masyarakat, sehingga setelah panen padi barulah masyarakat Worat-Worat melakukan kegiatan sosial di rumah adat sasadu dengan pelaksanaan tradisi orom sasadu, dan marupakan satu-satunya pesta adat yang ada pada masa itu sehingga pelaksanaannya selama tujuh hari tujuh malam. Hal ini juga dikemukakan oleh Visser (2019:247) bahwa persiapan untuk perayaan tradisi orom sasadu dimulai dengan sebuah pertemuan desa yang mengatur tanggal perayaan dan hal ini disetujui atas dasar berapa banyak tabung bambu untuk beras, berapa banyak ikan, berapa banyak angur aren, dari setiap rumah tangga yang harus disediakan, serta berapa banyak uang tunai dari setiap rumah tangga yang akan diminta untuk membeli rokok, gula, teh, dan juga ikan akan disajikan bagi para tamu dan undangan atas nama desa tuan rumah.

Masyarakat Desa Worat-Worat jaga berunding dan mempertimbangkan lamanya waktu pelaksanaan orom sasadu, yang kemudian di putuskan menjadi Tiga hari Hari tiga malam. Adapula yang mengurangi sampai Satu hari Satu malam dengan alasan kesibukan masyarakat yang sekarang bukan hanya sebagai petani saja melainkan sebagai pegawai negeri maupun pengusaha sehingga lamanya prosesi orom sasadu tidak selama pada masa yang lalu.

Pelaksanaan tradisi orom sasadu pada saat berdasarkan hasil kesepakatan dari pertemuan adat antara tokoh adat, toko masyarakat, dan kepala desa tentang waktu pelaksanaan tradisi orom sasadu yang kemudian disampaikan waktu pelaksaannya kepada pemerintah Daerah Kabupaten Halmahera Barat. Setelah disepakati waktu pelaksaan tradisi orom sasadu maka untuk melaksanakan upacara adat, masyarakat Desa Worat-Worat membutuhkan waktu persiapan selama satu minggu. Persiapan tersebut meliputi; pergantian atap, meja dan kursi rumah adat yang telah rusak, pembersihan alat musik, pengambilan tumbuhan yang akan dipakai sebagai tiang bendera dan pernakpernik rumah adat dan pembersihan rumah adat. peralatan yang akan dipakai serta makanan yang akan dihidangkan pada acara tersebut. 
Setelah ruang disiapkan dan peralatan seperti tifa dan gong diletakkan pada tempatnya, maka dimulailah acara pembukaan (ngale faturo) yang ditandai dengan menggantungkan kain putih berbentuk segi tiga mengelilingi Sasadu dan pengibaran bendera induk. Proses ngale faturo diiringi dengan pemukulan tifa, gong, dan pelepah daun sagu dengan irama kakabelu. Orang yangbertugas menggantungkan kain putih berbentuk segi tiga adalah masyarakat dari keturunan Walasae (pimpinan gam). Setelah kain putih selesai digantung dan bendera sudah dinaikan, maka rumah adat sasadu dinyatakan dibuka dengan resmi dan semua yang masuk dalam acara makan bersama harus menggunakan pakaian adat.

Pelaksanaan ritual adat orom sasadu pada malam hari, dimulai ketika matahari terbenam. Pada masa lalu, sebelum adanya agama resmi Indonesia memasuki sahu, prosesi ritual adat orom sasadu dilaksanakan selama tujuh hari tujuh malam, dari hasil wawancara dengan Yulius kadoda (Ketua Adat) bahwa:

"lamanya waktu pelaksanaan acara adat ini disesuaikan dengan jumlah atap pada Rumah adat sasadu yang berjumlah tujuh buah atap dilihat dari arah utara ke selatan pada rumah adat tersebut (1 atap panjangnya 1,5 meter). Jadi acara makan bersama ini dapat berlangsung selama Tujuh hari Tujuh Malam. Namun belakangan ini, karena alasan kenyamanan dan hal lainnya, maka kegiatan ini dibatasi menjadi 1 hari, malam dan siang. Tetapi masih ada juga yang menyelenggarakan acara makan bersama selama 3 (tiga hari), tergantung kesiapan masyarakat yang menyelenggarakan" (12/05/2019).

Makanan utama yang disajikan adalah nasi kembar (nasi cala) yaitu beras yang dimasak dengan cara dibungkus dengan dua sisi daun pisang kemudian digulung ke tengah-tengah batang sehingga menyatu lalu dimasukkan ke dalam bambu yang dimasak dengan cara dibakar. Lauk-pauk terdiri atas ikan dengan berbagai olahan, misalnya dibakar, goreng, bakar siram rica/cabe, sayuran, dan masakan dari daging.

Pada pesta atau acara makan adat ini tetua adat menggunakan pakaian kebesaran yang berbeda dari masyarakat lain. Orangorang yang duduk di tempat duduk utama menggunakan pakaian adat dan penutup kepala (bisa juga peci/songkok), sedangkan ibu-ibu juga menggunakan pakaian adat kebaya, ataukain bawahan, selempang yang diikatkan menyamping dari pundak sampai pinggang, dan rambut dihias dengan hiasan warna warni yang diselipkan pada sanggulnya. Sementara itu para laki-laki yang lebih muda yang bertugas melayani para tetua atau orang tua menggunakan pakaian yang berbeda yang terdiri dari baju adat, kain yang diikatkan di kepala, selempang pada pundak sampai pinggang. Para tamu juga harus menggunakan pakaian adat, jika tamu itu adalah tamu undangan harus menggunakan peci/songkok. Kepribadian dasar itu karena semua individu warga masyarakat WoratWorat mengalami pengaruh lingkungan kebudayaan yang sama selama masa pertumbuhannya.

Pelaksanaan rutual adat orom sasadu diawali dengan penjemputan para undangan yang biasanya pejabat di wilayah setempat (Bupati, Camat/Sangaji) dengan tarian-tarian adat dan selanjutnya ditempatkan pada tempat yang disebut taba sangaji. Masyarakat desa menempati tempatnya masing-masing sesuai dengan garis keturunannya. Pria dan wanita menempati tempat duduk terpisah yang telah diatur menurut ketentuan adat. Keturunan walasae menempati taba walasae (tempat duduk keturunan para pemimpin desa), keturunan walangatom menempati taba walangatom (tempat duduk keturunan prajurit). Jika dalam garis keturunan tokohtokoh adat tersebut ada yang meninggal, maka ada prosesi yang disebut si bere baba ma soi (mengangkat anak sulung menggantikan kedudukan orang tuanya yang sudah meninggal, yang ditandai dengan pegambilan 
sumpah adat) seterusnya ia menempati tempat duduk adat orang tuanya. Hal demikian juga dilakukan kepada kepala desa yang baru saja dilantik, dengan pengambilan sumpah untuk menjalankan tugas sebagai kepala desa yang amanah dan bijaksanan. Jika dalam menjalankan tugasnya dikemudian hari yang tidak sesui dengan fungsinya sebagai kepala desa dan kedapatan korupsi maka kepala desa disumpah oleh ketua adat dihadapan seluruh masyarakat Worat-worat dan tamu undangan bahwa jiga kepala desa berada di laut maka hewan laut akan memangsanya, dan hewan yang ada di hutan juga memangsanya bila berada di hutan.

Acara makan bersama kemudian dilanjutkan dengan nasihat (bobita) oleh kepala (tetua) adat. Bobita menyangkut hukum adat yang mengatur pola hidup masyarakat suku Sahu di antaranya sistem pertanian dan pembicaraan berkenaan dengan pesta adat yang perlu ditaati oleh Masyarakat Worat-Worat, yaitu hal-hal yang tidak diinginkan, misalnya soal moral, mabuk, kekacauan, perkelahian, dendam, dan sebagainya. Sanksi yang diberikan bagi yang sengaja membuat keributan pada acara ini adalah diikat pada tiang Sasadu, disiram dengan air kotor, disiram dengan saguer (minuman dari pohon Aren) atau dipukul dengan kayu pemukul tifa. Setelah selesai bobita disampaikan dilanjutkan dengan doa oleh pendeta. Acara dilanjutkan dengan sapaan selamat makan yang bersahutan antara kepala adat (KA) dan peserta (P). Seperti yang dikemukakan oleh Gaspar Yunga dari Hasil wawancara sebagai berikut:

\footnotetext{
“ $K A$ : lor nongo'du toma wanger ma sodu re wanger ma moto I'duang bolo nyang? (saudara-saudara dari matahari terbit/timur sampai matahari terbenam/barat sudah siap atau belum?)

$P \quad$ : d'uang d'ua si jou (sudah siap)

$K A$ : orom kie si jou (mari kita makan)

$P \quad$ :jou (ya)

$K A$ : Ior nongo'du toma mien re sara, I'duang bolo nyang? (saudara
}

\author{
saudara dari utara sampai \\ selatan sudah siap atau belum?) \\ $P \quad$ : d'uang d'ua si jou (sudah siap) \\ $K A$ : orom kie si jou (mari kita makan) \\ $P \quad$ :jou (ya)" (12/05/2019).
}

Acara makan bersama diiringi dengan pemukulan tifa dan gong disertai ma I'o (syair-syair yang didendangkan melalui lagu atau pantun secara berbalasan serta pementasan berbagai kesenian daerah). Acara ini juga disebut oleh masyarakat Worat-Worat sebagai acara "bebas" makan, minum, dan menari hingga pagi hari dengan diiringi musik tifa dan gong.

Keesokan harinya pada jam 15:00 WIT dilaksanakan acara puncak dari prosesi upacara orom sasadu yang disebut sebagai jiawa. Pada acara jiawa makanan yang dihadangkan berupa waji dan kukusan pada acara jiawa ini diawali dengan pembacaan doa yang dilanjutkan dengan seruan untuk mencicipi hidangan yang telah tersedia ajakan tersebut dikemukan oleh Gaspar Yunga pada saat wawancara bunyinya sebagai berikut:

Tego fakololi ino, paranatakokonara, tego fakololi meja, meja madopolo jou (mari duduk berhadapan dengan wajah yang ceriah, mari duduk berhadapan pada meja yang ditempati kepala desa). Setelah sudah ditempati tempat duduknya, kepala adat menyampaikan ungkapan sebagai tanda dimulainya makan bersama, bunyinya sebagai berikut: jou dai budo-budo, jou dia lamolamo, o tarima nanga jamuan, si jou" (tuan datang diiringi ombak di laut putihputih, tuan pergi dingin dengan angin yang kencang, terimalah jamuan makan bersama dan makanlah), kemudian setiap orang yang duduk di meja jiawa membalasnya dengan mengatakan si jou (makanlah), maka acara makan bersama di meja jiawa resmi dimulai $(12 / 05 / 2019)$.

Mencicipi makanan yang ada diiringi pukulan tifa dan gong yang dilangsungkan dengan tarian legu-salai yang dipentaskan oleh anak-anak yang merupakan bagian dari 
masyarakat desa Worat-Worat. Pada saat tarian adat dipentaskan di luar rumah sasadu maka tokoh adat dan masyarakat serta kepala desa yang ada di dalam rumah adat sasadu juga keluar dari rumah adat tersebut untuk menyaksikan tarian adat itu. Setelah beberapa jam dilaksanakanya terian tersebut maka selanjutnya tokoh adat, kepala desa, serta seluruh masyarakat yang merayakan tradisi orom sasadu mengelilingi sasadu sebanyak tiga putaran dan disertai dengan diputarnya wala jawa yang berada di bumbungan rumah adat dengan meksud memeriahkan prosesi jiawa tersebut. Setelah mengelilingi rumah adat tersebut pada pukul 18:00 WIT dilanjutkan dengan penurunan bendera induk yang menandakan bahwa prosesi upacara adat telah usai dilaksanakan. Setalah usai dilaksanakannya tradisi orom sasadu dipersilakan kepada anak-anak untuk memainkan alat musik berupa tifa dan gong sebagai proses pembelajaran dalam memainkan alat musik tersebut.

\section{Makna dan Nilai dalam Tradisi Orom sasadu di Desa Worat-Worat}

Sebagai pemilik rumah adat sasadu, masyarakat worat-worat memiliki falsafah yang mengibaratkan rumah sasadu sebagai sebuah 'kagunga' (kapal perang kerajaan Ternate) jika dilihat dari bentuknya rumah sasadu memiliki bentuk seperti perahu yang terbalik seperti yang dikemkukakan oleh Visser (2019:273) bahwa rumah adat sasadu sebagai suatu perahu yang terbaring. Menurut Masyarakat Worat-Worat, rumah sasadu adalah 'kagunga tego-tego', artinya kagunga (Kapal perang) yang ada di darat. Hal ini dikarenakan pada masa lalu sebagian dari masyarakat Worat-Worat merupakan armada laut kerajaan Ternate yang mengendarai kagunga tagi-tagi (kapal perang yang ada di laut) sehingga rumah sasadu di ibaratkan seperti kapal perang yang ada di darat, untuk mengenang para leluhur sebagai para pelaut. perbedaan sasadu di Worat-Worat dengan di tempat lain berbeda pada sisi atapnya, sasadu di Worat-Worat memiliki tambahan bangunan di puncak sasadu yang di sebut sebagai valajawa. Menurut ketua adat walajawa merupakan pemeberian Sultan ternate kepada leluhur masyarakat Worat-Worat sebagai sebuah bentuk arsitektur sehingga para leluhur menempatkannya di puncak sasadu.

Tradisi makan bersama (orom sasadu) pada masyarakat Worat-worat merupakan pesta adat yang pada prinsipnya dilaksanakan untuk mensyukuri panen padi yang telah dianugerahkan oleh sang pencipta serta membangun kekerabatan dalam hubungan sosial dengan sesamamanusia. Menurut Pudenita dalam Irwanto (2012:124), bahwa, di dalam setiap pertunjukan terkandung makna penciptaan sebuah karya atau dengan kata lain dapat dikatakan bahwa setiap penuturan atau setiap pertunjukan adalah sebuah kreasi atau komposisi. Melalui orom sasadu, masyarakat juga diajarkan untuk memaknai hubungannya dengan lingkungan alam sekitar, tempat di mana mereka diajarkan untuk memahami waktu-waktu khusus untuk menanam, menuai, dan "mengistirahatkan" tanah sebagai bagian dari sistem pertanian yang dianut masyarakat Worat-Worat.

Tradisi orom sasadu ini tidak hanya dipahami sebatas makan bersama tetapi lebih jauh dari itu adalah pemaknaan kembali nilainilai yang terkandung dalam aturan-aturan alam yang telah digariskan sejak kehidupan para leluhur yang meletakkan dasar-dasar kehidupan bermasyarakat. Nilai-nilai yang terkandung dalam prosesi upacara adat tradisi orom sasadu diantaranya:

\section{Nilai Sosial}

Upacara adat orom sasadu mengajarkan masyarakat Worat-Worat untuk tidak menduduki tempat yang bukan miliknya. Artinya tradisi orom sasadu memberi kesan kepada masyarakat Worat-worat dalam kehidupan kesehariannya tidak mengambil barang milik orang lain, dan selalu tunduk dan menghargai orang yang lebih tua, begitu pula orang yang lebih tua dalam masyarakat 
Worat-Worat harus menunjukan hal yang baik kepada yang muda.

2. Nilai Moral

Hal ini tercermin pada saat ketua adat menyampaikan nasihat-nasihat diantaranya tidak boleh menyinggung hutan sesama pada saat upacara adat kemudian tidak boleh mengacaukan prosesi upacara adat, bila kedapatan akan diberi hukuman. Hal tersebut membntuk karakter masyarakt Worat-worat menjadi pribadi yang labih baik.

3. Nilai Kebersamaan atau Gotong Royong

Pelaksanaan tradisi orom sasadu mulai dari masa persiapan hingga penutupan masyarakat Worat-Worat melakukanya secara gotong royong, hal ini dikarenakan sistem gotong royang oleh masyarakat Worat-worat telah ada pada masa lalu. Bagi leluhur masyarakat Worat-worat bila mengerjakan sesuatu misalnya, membuka lahan pertanian jika dilakukan secara gotong royang, dilakukan dengan muda dan cepat selesai tidak seperti dikerjakan oleh perseorangan yang pekerjaannya terasa berat dan menempuh waktu yang lama dalam proses pembuatan lahan. Sehingga pada saat ini msyarakat Worat-worat selalu bekerja sama atau gotong royong baik untuk membangun rumah adat ataupun bekerja sama dalam melakukan pekerjaan keseharian masyarakat Worat-Worat.

\section{Nilai Religius}

Hal ini tercermin pada prosesi upacara adat sebagai upacara syukuran panen padi yang dilaksanakan oleh masyarakat woratworat pada masa lalu jugamengajarkan masyarakat Worat-Worat yang hidup pada masa kini agar selalu mensyukuri kehidupan yang dijalani oleh masyarakat Worat-Worat baik suka maupun duka, dan tak lupa mensukuri tiap berkat yang diberikan oleh Tuhan atas hasil panen masyarakt WoratWorat berupa kelapa, pala, cengkih, buahbuahan dan hasil alam lainnya.

\section{Nilai Budaya}

Prosesi upacara adat orom sasadu sebagai wujud ucapan syukur kepada Tuhan, juga merupakan pelestarian budaya yang telah ada pada zaman dahalu yang dilestarikan hingga pada saat ini. Pelestarian budaya sebagai bahasa dan kesenian yang merupakan unsur dari kebudayaan tercermin pada saat prosesi upacara adat. Bahasa yang digunakan pada saat prosesi adat, yakni bahasa suku sahu talai. Dalam pembacaan susunan acara ritual adat menggunakan bahasa sahu talai yang di bacakan oleh dua orang anak secara berbalasbalasan. Secara tidak langsung dari prosesi upacara tersebut mengajarkan kepada generasi masyarakat Worat-worat untuk memahami bahasa daerah dan melestarikannya. Selain bahasa adapulah tarian yang pentaskan oleh anak-anak, berupa tarian legu-salai hal ini juga mengajarkan kepada generasi penerus masyarakat Worat-worat untuk melestarikan terian tersebut.

\section{KESIMPULAN}

Tradisi orom sasadu Merupakan, ritual adat masyarakat suku sahu pada umumnya dan masyarakat Worat-Worat khususnya. Tradisi orom sasadu telah dilaksanakan oleh leluhur masyarakat Worat-Worat, dan masi dilestarikan hingga saat ini.Oleh karena itu, dapat disimpulkan bahwa (1) Pada masa lalu masyarakat Worat-worat tekenal dengan hasil panen padi oleh karerena itu tradisi orom sasadu perlu dilestarikan bagi generasi selunjutnya dan dijadikan sebagai motivasi dalam bercocok tanam; (2) Tradisi orom sasadu dalam pelaksanaannya diadakan pertemuan oleh masyarakat Worat-worat dengan tokoh adat, dan juga pemerintah untuk menentukan waktu pelaksanaan ritual adat tradisi orom sasadu. Menata ruang dalam rumah sasadu serta pemasangan bendera putih segitiga yang mengililingi sasadu dan meletakan alat musik seperti tifa dan gong pada tempatnya. Pelaksanaan, diawaili dengan penjempputan tamu undangan yang dilanjutkan dengan ajakan untuk menikmati hidangan yang telah disediakan dan seluruh 
masyarakat menikmati hidangan yang ada dengan penuh suka cita. Penutupan, yakni menurunkan bendera induk dan melepaskan bendera putih segi tiga yang dipasang mengelilingi sasadu; dan (3) Makna dari pelaksanaan tradisi orom sasadu sebagai syukuran hasil panen padi. Nilai yang terkandung dalam perayaan tradisi Orom sasadu yakni; nilai sosial yang mengajarkan kepada masyarakat Worat-Worat untuk saling menghargai, nilai moral mengajarkan masyarakat Worat-Worat untuk tidak membuat keributan, nilai kebersamaan atau gotong royong mengajarkan kepada masyarakat Worat-Worat untuk selalu bergotong royong dalam melakukan suatu pekerjaan, nilai religius masyarakat WoratWorat untuk selalu bersyukur kepada Tuhan atas hidup yang dijalani baik suka maupun duka dan selalu bersukur akan hasil alam yang Tuhan berikan, dan nilai budaya dengan adanya tradisi orom sasadu mengajarkan generasi penerus Masyarakat Worat-Worat untuk tetap melestarikan kebudayaan masyarakat Worat-Worat berupa bahasa dan tarian adat.

\section{DAFTAR PUSTAKA}

Fathoni, Abdurrahmat. (2006). Antropologi Sosial Budaya Suatu Pengantar. Jakarta: Reneka Cipta.

Hikmansyah. (2016). Bentuk Dan Fungsi Rumah Sasadu Sebagai Pusat Kegiatan Masyarakat Sahu Kabupaten Halmahera Barat Maluku Utara. Prosiding Seminar Nasional. Sustainable Architecture And Urbanism.Vol 8 .No.1

Irwanto, Dedi. (2012). Kendala dan Alternatif Penggunaan Tradisi Lisan Dalam Penulisan Sejarah Lokal di Sumatera Selatan. Jurnal Forum Sosial, Vol. V, No. 02.
Jamaludin, A.N. (2016). Sosiologi Pedesaan. Cv. Pustaka Setia: Bandung

Koentjjaraningrat (2002). Pengantar Ilmu Antropologi.Cet 8. Jakarta: PT. Reneka Cipta

Miles M.B \& A. Michael Huberman. (2014). Analisis Data Kualitatif. Terjemahan Tjetjep Rohendi Rohidi. Jakarta: UI Press

Moleong J. L. (2014). Metodologi Penelitian Kualitatif. Bandung : PT Remaja Rosdakarya.

Sutopo, H. B. (2006). Penelitian Kualitatif Dasar Teori dan Terapannya dalam Penelitian. Surakarta: Universitas Sebelas Maret.

Soekanto, Soerjono. (2006). Sosiologi Suatu Pengantar. Jakarta: Rajawali Press.

Sztompka, P. (2011). Sosiologi Perubahan Sosial. Cet 6. Jakarta: Prenada.

Visser, E. Leontine (2019). Sejarah Pertanian dan Kebudayaan di Sahu Halmahera. Yogyakarta: Ombak. 